\title{
Indigenous leaders call for control of health care
}

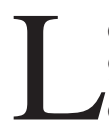

eaders representing more than 975000 indigenous peoples called on the federal government to overhaul radically its approach to managing their health care and expediting indigenous control over health policy and delivery.

Responding to that call was Ottawa's top official for indigenous health. Dr. Tom Wong, executive director for the Office of Population and Public Health at Health Canada's First Nations and Inuit Health Branch, said he was personally committed to seeing Ottawa transfer control of health care into indigenous hands. "I totally agree," Wong said. "That's the way to make things better. The way that different regions choose to do it may be somewhat different, but community control of health services is the way to go."

The call to action came from the Assembly of First Nations, the Métis Nation of Ontario and the Inuit Tapiriit Kanatami on May 26 at the Indigenous Health Conference: Towards Health and Reconciliation, in Toronto.

Natan Obed, president of the Inuit Tapiriit Kanatami, representing 60000 Inuit, said he welcomed the federal government's decision in late February to include First Nations, Métis and Inuit organizations alongside the provinces and territories in the negotiations for a new Health Accord.

"We are encouraged by the language of the new federal government that talks of renewal of an Inuit-toCrown relationship," Obed said in a speech to 700 conference delegates.

But Obed made it clear that he does not assume Ottawa's softened rhetoric will lead to results.

Inuit control of health research is urgently needed, said Obed. The Inuit have been inundated with "small programs" that overlook systemic problems, he added. According to Obed, the myriad problems facing the Inuit include the facts that almost all

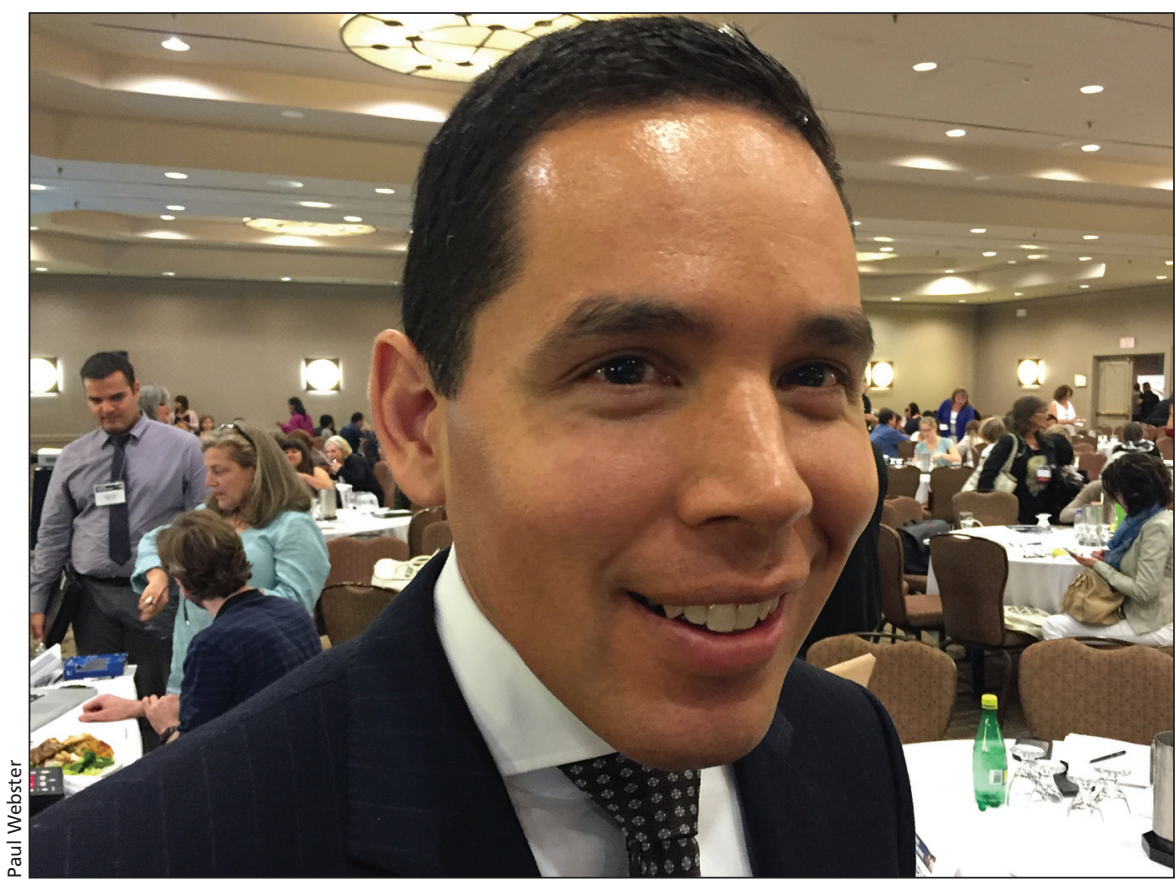

Natan Obed, president of an organization representing 60000 Inuit, said they have been inundated with "small programs" that overlook systemic problems.

expectant women relocate thousands of kilometres from their communities to give birth; $70 \%$ of preschoolers in Nunavut live in homes with food insecurity; tuberculosis rates are vastly higher than the rest of Canada; suicide levels are among the highest in the world; almost no health care services are available in Inuit languages; there is no addiction treatment centre in the far North; and Inuit have been largely excluded from participation in health research.

"Our population has cried out for interventions and care in our homeland for a generation," Obed said. "We have the money, but are we willing to do it?"

Ontario Regional Chief Isadore Day, head of the health committee of the Assembly of First Nations, representing 900000 First Nation citizens, warned that the federal government has yet to begin to meet the health care commitments it made in the runup to last year's election.
"We're still waiting for the government to see the connection to the systemic issues. At the root is chronic underfunded health systems," Day said. "We need Canada to fix this." He favours scrapping the 1876 Indian Act entirely. The assembly is pleased to be included in the upcoming Health Accord negotiations, he adds.

Margaret Froh, President of the Métis Nation of Ontario, representing 18000 registered members, called on indigenous groups to work constructively with the federal government to overcome health inequities, which she traces to the legacy of colonialism. Like Obed and Day, she said indigenous groups' inclusion in the Health Accord negotiations is a promising first step.

Wong endorsed the leaders' calls for clean water, affordable food, and safe homes. "How difficult is that?" he asked. - Paul Webster, Toronto, Ont.

CMAJ 2016. DOI:10.1503/cmaj.109-5287 